\title{
Islamic Perspectives
}

\section{Prospects and Ethics of Stem Cell Research: An Islamic Perspective}

\author{
Hossam E. Fadel, MD, PhD, FACOG \\ Director of Maternal Fetal Medicine, University Hospital \\ Clinical Professor, Department of Obstetrics and Gynecology, Medical College of Georgia \\ Augusta, Georgia
}

\begin{abstract}
:
Stem cells (SCs) are pluripotent cells that retain the ability to develop into all cell types. This characteristic makes them appealing for use in research with view of therapeutic use, especially in "regenerative medicine." Stem cell sources include the following:
\end{abstract}

1. Embryonic stem cells (ESCs): These are derived from the inner cell mass of developing embryos.

2. Adult stem cells (ASCs): The best known source of ASCs is the hematopoietic cells of the bone marrow. These have been used clinically with good results in the treatment of leukemias. Very few ASCs may be present in other organs, e.g. the brain.

3. Cord blood: Cord blood is another source of "adult" hematopoietic stem cells. 4. Therapeutic cloning: Therapeutic cloning utilizes nuclear transfer techniques to produce pluripotent SCs with the genome of the nucleus of origin. These cells can be induced to differentiate into replacement cells for transplantation into the individual from whom the original cell was obtained, thus eliminating the requirement of immune suppression.

In this paper I will discuss the potential and realized gains of stem cell therapies as well as the potential problems associated with their use. I then will discuss the ethical dilemma that this research entails as it deals with the human embryo. I will discuss the moral status of the embryo and the varying views of ethicists in this regard and then I will discuss the opinion of religious communities and, specifically, the Islamic perspective. Islamically, stem cell research is probably permissible, except for the creation of embryos for the specific purpose of using them only in research. Therapeutic cloning will be Islamically acceptable when the intent is to create tissue/organ from the individual who needs it, the procedure is feasible, and the result is expected to be good.

Finally, I will discuss the present status of stem cell research in the United States and the politics that impact it.

Key words: Human embryonic stem cells, adult stem cells, umbilical cord blood stem cells, stem cell research, somatic cell nuclear transfer, regenerative medicine, ethical considerations, Christianity, Judaism, Islam, Islamic shariah, politics and science. 
S tem cell research is a relatively new field of medicine that has great promise but has led to confrontation with established religious and moral values. It already has generated heated debate regarding the boundaries of scientific research that it should not cross.1,2

In this paper I will explain, in the most basic terms, what stem cell research is, what its goals are, and when it may conflict with religious and moral values. I then will discuss the ethical principles that may guide us in establishing a balance and the positions of various religions, specifically Islam.

\section{What are Stem Cells?}

Stems cells are simply the "original" cells from which all 210 different kinds of cells that make the human body develop. ${ }^{3}$ They can be classified into:

1. Totipotent cells: These are the cells that can generate a complex organism, be it animal or human, but they cannot self regenerate. These are the embryonic cells beginning with the zygote until the 8-cell morula stage.

2. Pluripotent cells: These cells retain the capacity to transform into all three primary germ layers i.e., the endoderm, mesoderm, and ectoderm and, therefore, can still form a complex organism. They can - in contrast to the totipotent cells - self renew, for example in tissues culture. These are the cells of the inner cell mass of the blastocyst and constitute what are usually called embryonic stem cells (ESCs).

3. Mulitpotent and progenitor cells: These cells in the developing embryo are the descendants of the inner cell mass. They are already differentiated and develop in specific types of cells e.g. blood cells, liver cell, cardiomyocytes, neurons, etc., and eventually make the different body organs (Figure 1).

Stem cells are also present in adult tissues and organs in small numbers with a limited potential of self-renewal. They may be able to replace lost or damaged cells. It is unknown to what extent they may (or be made to) transdifferentiate into cells of other lineage. They have been found in the brain, eye, bone marrow, peripheral blood, skin, liver, etc. They are also in the umbilical cord blood. ${ }^{4}$

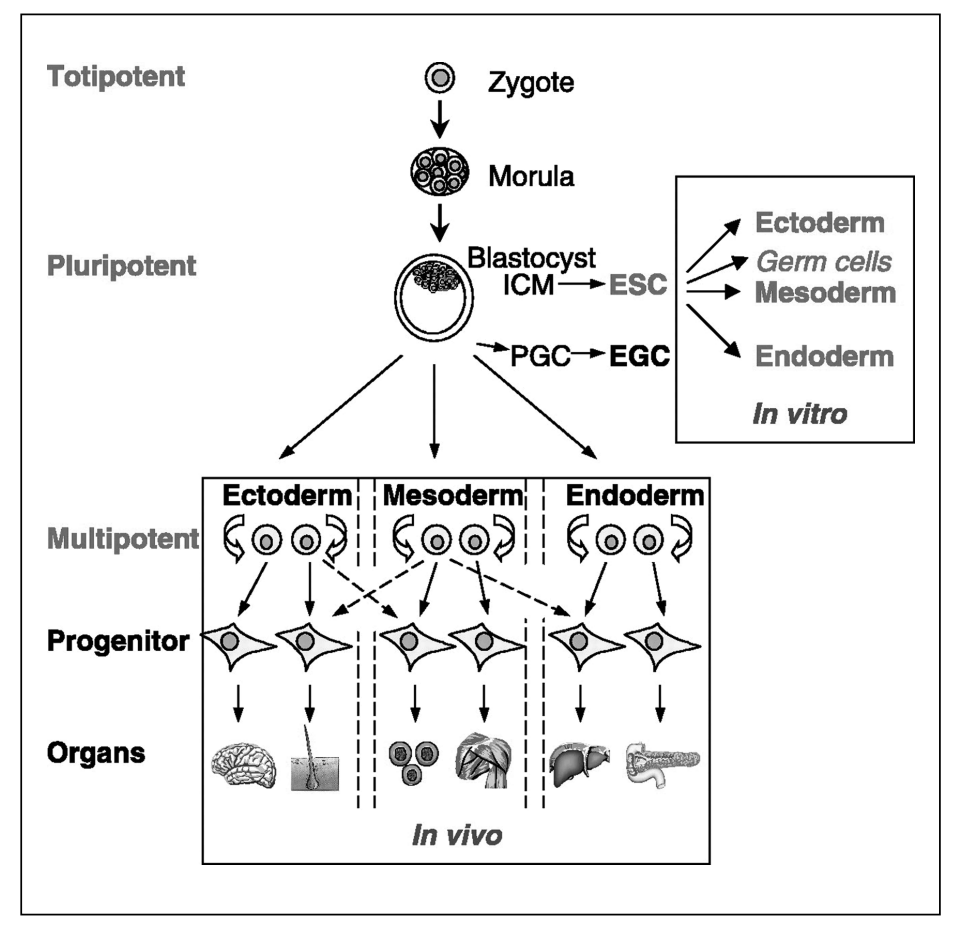

Figure 1. Stem cell hierarchy. Zygote and early cell division stages (blastomeres) to the morula stage are defined as totipotent because they can generate a complex organism. At the blastocyst stage, only the cells of the inner cell mass (ICM) retain the capacity to build up all three primary germ layers, the endoderm, mesoderm, and ectoderm, as well as the primordial germ cells (PGC), the founder cells of male and female gametes. In adult tissues, multipotent stem and progenitor cells exist in tissues and organs to replace lost or injured cells. At present, it is not known to what extent adult stem cells may also develop (transdifferentiate) into cells of other lineages or what factors could enhance their differentiation capability (dashed lines). Embryonic stem (ES) cells, derived from the ICM, have the developmental capacity to differentiate in vitro into cells of all somatic cell lineages as well as into male and female germ cells. [Reproduced with permission from Wobus and Boheler, 2005.3]

\section{Embryonic Stem Cells}

Most ongoing research has been utilizing embryonic stem cells (ESCs), which are derived from the embryonic inner cell mass and kept growing in tissue culture (Figure 2). Most studies were made on murine ESCs, but there also has been great demand for human ESCs (hESCs) because they are believed to be much more promising in the search for cures of 
human disease. Human embryos have been created by in vitro fertilization (IVF) specifically for stem cell research, but more commonly human embryos used for stem cell research were supernumerary embryos left over from IVF done for reproductive purposes and donated by the couples concerned. Attempts also have been made to use spontaneously aborted fetuses but mostly these cells fail to grow in culture. Also, cloned embryos have been developed through the procedure of somatic cell nuclear transfer (SCNT), which is sometimes called therapeutic cloning, a procedure that will be discussed later. ${ }^{1}$

\section{Realized and Potential Benefits of Stem Cell Research}

There have been realized benefits of stem cell research, the best known of which is the successful treatment of leukemia and many other hematologic disorders by bone marrow transplants and, more recently, by using umbilical cord blood stem cells. However, the real promise of stem cell research is the potential development of a new field of "regenerative medicine," 5 which aims at growing tailormade human tissues or organs to be used to colonize or to replace damaged tissues/organs to recover their lost function. Progenitor cells have been developed that can be made to differentiate into myocardial cells, neurons, and pancreatic as well as other types of cells (Figure 3). These cells can potentially be used to treat Parkinson's disease, Alzheimer's disease, and patients with spinal cord injuries. It is speculated that they will also be used in the treatment of type 1 diabetes, myocardial infarction as well as other conditions. I will mention just a few examples of such studies. Dopaminergic cells generated from primate embryonic stem cells were transplanted into monkeys with MPTP-induced Parkinson's-like disease. These transplanted cells attenuated the neurological symptoms. ${ }^{6}$ Laminectomized mice received contusion spinal cord injury. Human CNS stem cells were transplanted to an adjacent region. These CNS SC transplants promoted locomotor receovery. ${ }^{7}$ Wistar rats were randomized into control myocardial infarction (MI), MI plus transplanted cord blood stem cells, and sham groups. Cord blood transplants increased mRNA expression of vascular endothelial growth factor and promoted a higher level of angiogenesis in the infarct zones. Echocardiography demonstrated improved left ventricular function in the treatment group compared to MI controls. ${ }^{8}$

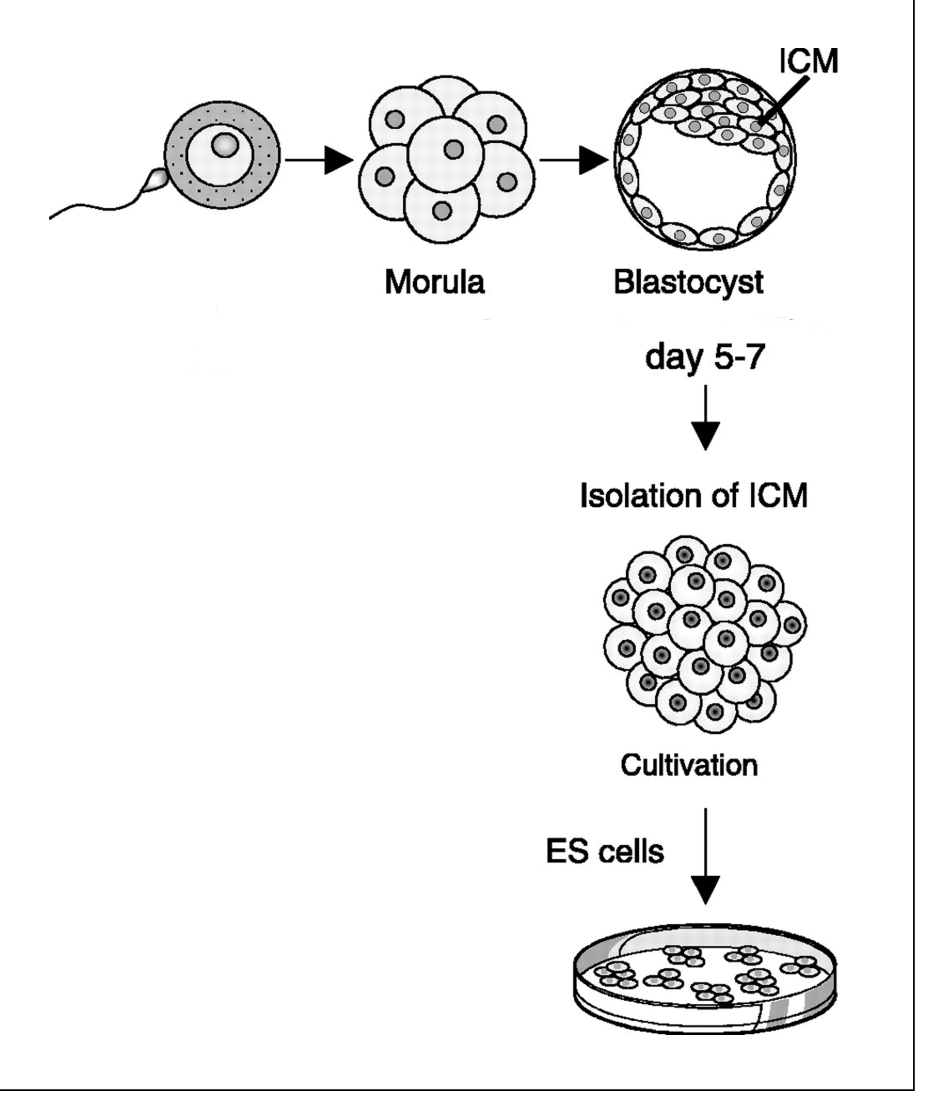

Figure 2. Human pluripotent embryonic stem cells (hESCs) have been derived from in vitro cultured ICM cells of blastocysts (after in vitro fertilization). [Adapted with permission from Wobus and Boheler, 2005.3]

There is a growing number of clinical trials investigating the use of stem cells to treat heart conditions. There were 57 such trials from 2000-2005 and 87 in 2006 alone. 9

It is to be emphasized, however, that these potential benefits and the prospect of stem cell therapy are still a long way from being a part of clinical practice.

Another important potential benefit is in the field of pharmacology. ${ }^{3}$ ESCs can be used to identify new molecular targets for drug therapy and thus facilitate the development of novel drugs. Also, research can be directed to test the safety of drugs and to predict their potential toxicity in vitro (culture) and reduce the need for animal testing in pharmacotoxicology. Of special importance is its use in the field of embryotoxicology. ${ }^{3}$ It can be used to identify the primary molecular mechanisms responsible for the teratogenic effect of drugs. For example, thalidomide was found to inhibit angiogenesis by the generation of hydroxyl radicals. When testing med- 
ications in growing cultures of ESCs becomes practical, it will eliminate the need for the use of experimental animals, which has been plagued by the problem of interspecies variation.

\section{Potential Problems with Stem Cell-Based Therapies}

Approximately one genetic mutation occurs with each cell division. ${ }^{3}$ The multitude of cell divisions that will have to be part of the process of stem cell-based therapies may add up to significant genetic mutations that may cause serious health problems. In addition, epigenetic modifications such as DNA mutation may also occur. Another serious consideration is that the stem cells are programmed to divide, and, if this division continues uncontrolled, it may lead to tumorigenesis. Also, implanted ESCs are going to be immunogenic, and graft rejection is possible.

Scientists are cognizant of these complications and realize that, along with the pursuit of stem cell research applications for therapy, strategies to produce techniques that enhance the possibility of reversibility should be developed as well before stem cell research enters into the clinical realm. ${ }^{3}$ So at this stage it behooves scientists, while emphasizing potential benefits of stem cell therapy, not to exaggerate these benefits. ${ }^{10}$

\section{Somatic Cell Nuclear Transfer (SCNT)}

In this procedure, ${ }^{3}$ a somatic cell is obtained (by biopsy) from an individual. A human oocyte is obtained from an egg donor. The oocyte is enucleated and then fused with the biopsied cell, transferring its nucleus to the new cell, which is then induced to develop into an embryo in a process akin to that used in cloning, and hence the name therapeutic cloning. As the blastocyst forms, the inner cell mass is isolated and cultivated to produce ESCs, which are then induced to differentiate into various cell types, eventually producing a tissue to be used as an autologous tissue graft to the original person from whom the somatic cell was obtained (Figure 4). If the procedure is successful, it can be used to clinically derive the somatic cell from a diabetic patient, for example, and generate pancreatic cells to be transplanted in that person. If they function properly, the person will be cured of diabetes. The new transplanted pancreatic tissue will have the sick person's DNA and antigens. There will be no need for immunosuppression. There will be no danger of organ/tissue rejection.

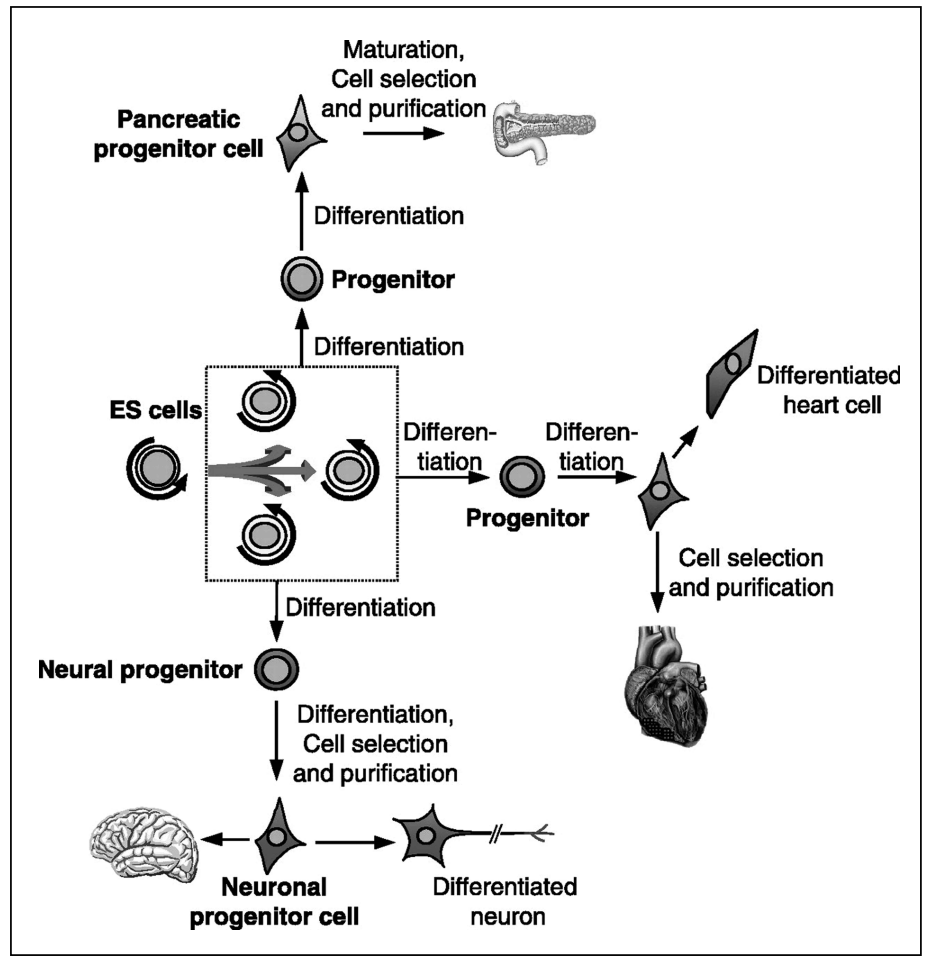

Figure 3. Proposed strategies of cell therapy using human ES cells for the treatment of heart and central nervous system diseases and diabetes. Pluripotent human ES cells must first be propagated in vitro. ES cells may then be selectively differentiated into cardiac, neural, or pancreatic progenitor cells, which have the capacity for terminal differentiation in vitro. Defined progenitor cells are selected and purified, followed by further differentiation/maturation and transplantation into the injured or damaged tissue to integrate and develop into functional cardiomyocytes, neurons, and pancreatic endocrine cells, respectively. For the treatment of cardiac infarcts or diabetes, mature cells may be necessary, whereas for the treatment of neurodegenerative diseases, neuronal progenitor cells could be applicable. [Reproduced with permission from Wobus and Boheler, 2005.3]

Additional potential benefits of this technology are the ability to study the pathogenesis of genetic disease. The procedure allows the production of hESCs from predefined individuals with the specific genetic diseases to be studied. It has the potential to allow for the study of methods to correct the genetic defect in the pluripotent stem cells. These cells can then be transplanted into experimental animals to test whether such gene correction precluded disease development. This can ultimately lead to the possibil- 
ity of correction of abnormal genes in vivo or the production of drugs that act on the proteins encoded by the pathogenic genes. ${ }^{5}$

\section{Umbilical Cord Blood as a Source of Stem Cells}

Umbilical cord blood (UCB) is a valuable source of hematopoetic stem cells. ${ }^{11}$ It was first used in 1988 to treat Fanconi's anemia in a sibling. Its major advantage is that it is less immunogenic. Only 4 out of 6 HLA antigen matches are used in contrast to bone marrow transplant where 9 out of 10 or even 10 out of 10 matches is required, yet it yields comparable clinical outcomes. For the same reason, UCB transplants are associated with a lower incidence of acute graft versus host reactions. However, the cell dose is approximately $10 \%$ of an adult bone marrow donor unit, so it can be used only in children or small adults.

Another major advantage is that it does not raise the ethical objection that is intrinsic to the use of hESCs.

At least $60 \mathrm{mls}$ of UCB are collected at delivery. Stem cells are separated and cryopreserved. Cryopreserved stem cells can survive for at least 15 years. Autologous use is possible, except for inborn errors of metabolism and many types of leukemia. However, it can be used even for these conditions for siblings and or parents. Cord blood transplanting has been successful in the treatment of many hematologic, immunologic, metabolic, and oncologic diseases. ${ }^{11}$ Its use is rapidly expanding into new areas including regenerative medicine e.g. the treatment of diabetes. ${ }^{12}$ For more details and information about newer clinical applications, see Young (2006).13

\section{Use of Adult Stem Cells in Therapy}

As mentioned earlier, few stem cells are found in many adult tissues. Hematopoeitic stem cells from bone marrow were coaxed to differentiate into neural, myogenic, and hepatic cell types. ${ }^{13}$ Neural and skeletal muscle cells were coaxed to develop into hematopoeitic cells. Stromal stem cells were coaxed to develop into cardiac myocytes. Mensencymal stem cells were made to develop into adipocytic, chondrocytic, or osteocytic lineages. The main advantage of ASCs is that they will not provoke immune system rejection and that they should not become cancerous, in addition to the fact that their use does not raise serious ethical or moral objec-

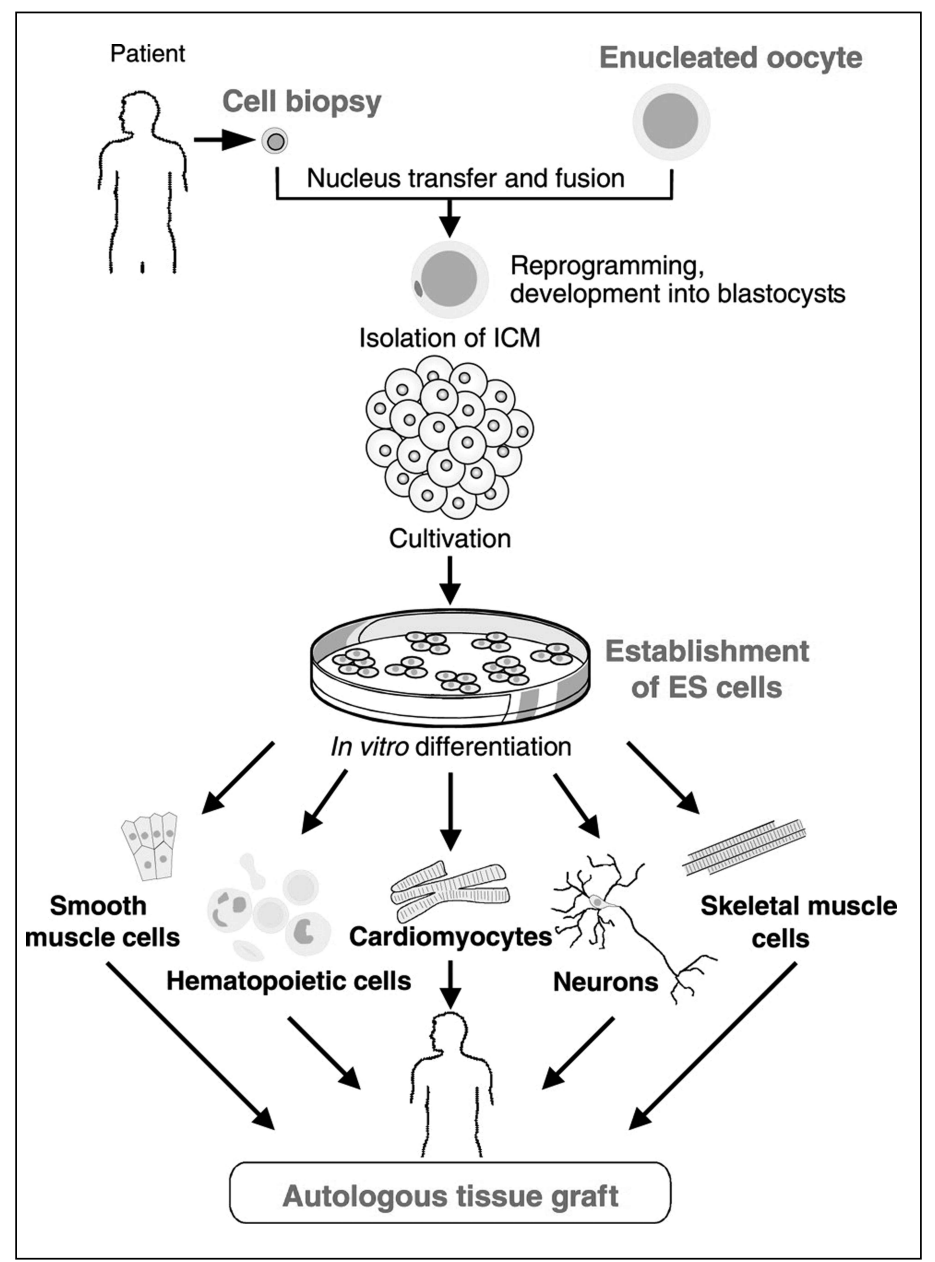

Figure 4. Strategy of human "therapeutic cloning" to generate autologous tissue grafts. Somatic donor cell nuclei are fused to enucleated oocytes. In the context of the oocyte cytoplasm, the genome of adult cells is reprogrammed to an embryonic status. From this embryo, blastocysts are developed and are used to establish human ES cells. These ES cells are subsequently differentiated in vitro into the desired cell type to generate an autologous tissue graft for transplantation. [Reproduced with permission from Wobus and Boheler, 2005.3]

tions. On the other hand, the transdifferentiation potential for most ASCs is probably limited compared to the unlimited transdifferentiation potential of the pluripotent hESCs. Further, ASCs ${ }^{1,2}$ are rare compared to the abundant hESCs that can be obtained, and ASCs are hard to grow in vitro. ${ }^{4}$

\section{Ethical Considerations}

From what has been discussed so far, the use of hESCs holds the greatest promise. At the same time, it is the one that has created the greatest controver- 
sy. Because of the use of human embryos and the objection of many in the religious/ethical communities, politics has been introduced into the realm of this scientific endeavor to an unprecedented extent in the form of legislation, presidential executive orders, and the single presidential veto so far. Embryonic stem cell research brings into conflict two moral principles:

1. The duty to respect human life.

2. The duty to reduce human suffering.

The dilemma is whether we as a society can agree on which of these two principles ought to be given precedence or if we agree that there is a time in the development of the embryo that it cannot be considered "human" and worthy of the "full" protection accorded a fetus or a live born infant.

The question then revolves on determining the moral status of the human embryo.1,14 There are three positions:

1. The fertilized egg (zygote) has a full moral status. ${ }^{15}$

2. While the fertilized egg has a moral status, it becomes deserving of protection only at a later stage. The moral status increases as the fertilized egg becomes more human-like. ${ }^{16}$

3. The embryo has no moral status at all; it is an organic material with a status no different from any other body part. ${ }^{14,17}$

Those who believe that the fertilized egg has a full moral status argue that there is no nonarbitrary point or morally significant dividing line in the continuum of physical growth between an embryo and a developed human. Therefore, the human embryo is a potential person from the time of fertilization. Their point is that while it is true that an embryo does not exhibit the properties of personhood, it will if allowed to develop and fulfill its potential.18,19

The proponents of the second opinion agree that the fertilized egg is potentially a person but they argue that there are degrees of value of a life depending on the stage of this life. Consequently, there are degrees of respect that ought to be shown to that life. They define these following stages: a) fertilization to implantation at the 6th day, b) from the 6th day (implantation) to the appearance of the primitive streak at the end of the second week, and c) viability, which has traditionally been set at 24 weeks. They argue that the rights of the human embryo/fetus increase as it goes from one of these stages to the next.

The last group states that the embryo has no moral status. It argues that fertilized human eggs/embryos are merely parts of other peoples' bodies. They claim that for a "being" to be destroyed that being should have an interest that is defeated. They further argue that for a being to have an "interest" this being must have beliefs, desires, expectations, aims, and purposes and that the embryo has none of these. ${ }^{20} \mathrm{I}$ believe that this position is extreme and can not be accepted on a moral/ethical ground. It denies that this being is a new creation of God.

Many ethicists have taken a reasonable middle ground view. They point out that before implantation (6-7 days after fertilization), the blastocysts can not grow independently. They thus argue that a stage in the development of the embryo ending at the second week (after fertilization), at which time the primitive streak appears, can be defined. The primitive streak defines the head-tail and right-left orientation of the embryo and along which the major tissues and organs begin to develop. This stage has been called the pre-embryo. The pre-embryo has no nervous system and cannot be considered sensate. ${ }^{21}$ Also, at the end of the second week there is no more possibility of twinning. ${ }^{19}$ At that time, the preembryo becomes an embryo and acquires a unique personhood. In this view, the early human embryo has an "intermediate" moral status. Thus, the preembryo and, particularly before implantation, the blastocyst can be used for experimentation i.e. stem cell research. However, special respect needs to be given by limiting their use to important human purposes, establishing guidelines for the research, and developing procedures to ensure that these guidelines are followed.

Proponents of this view support their argument with the observation that in natural reproduction, many fertilized eggs either stop developing or fail to implant and are "lost". We as a society do not grieve the natural loss of these fertilized eggs the same way we grieve the death of an infant. Therefore, we should not be too concerned about the loss of some embryos in the process of stem cell research. ${ }^{18}$

Further, IVF procedures generate many embryos 
which are found to be "nonviable" and will be discarded. These instead could be used for research.13

\section{Use of Human Embryos for Stem Cell Research}

The most widely available source is the supernumerary fertilized eggs produced during the course of IVF procedures. These are commonly cryopreserved for possible future use by the couples who produced them, but often they are never used and can be an adequate source for stem cell research. However, obtaining stem cell lines from fresh human embryos is more efficient than from cryopreserved embryos. It is estimated that only $10 \%$ of frozen embryos can be induced to develop into blastocysts. ${ }^{22}$ Thus, the use of fresh zygotes/embryos is more attractive. Fresh nonviable fertilized eggs produced during IVF procedures or fertilized eggs produced during IVF procedures performed for preimplantation genetic diagnosis could be another source. Some have advocated asking the couples undergoing IVF for fertility to donate some of the fresh viable fertilized eggs for research instead of having them cryopreserved for possible future use. Clearly this may reduce the chance of a successful pregnancy and increase the risk of going through additional cycles of IVF to achieve a pregnancy instead of using already cryopreserved fertilized eggs from a previous IVF cycle. However, ethicists agree that it will be permissible to approach these couples with the idea of donating some of the excess fertilized eggs so they are not deprived of the chance to contribute to science if they choose to do so. Detailed and comprehensive counseling should be provided in these cases, and a consent form signed by the couple should be thorough. On the other hand, in some institutions, physicians do not mention the possibility of donating embryos for that purpose until a couple indicates a wish to discard their remaining embryos. As a precaution it is suggested that decisions to donate embryos in infertility clinics should not be influenced by stem cell scientists. 22

\section{Ethical Considerations with Somatic Cell Nuclear Transfer (SCNT)}

The misconception that $\mathrm{SCNT}$ is reproductive cloning is the result of it being called "therapeutic cloning" in the popular nomenclature. SCNT is not reproductive cloning. Its opponents argue that this is a first step along a slippery slope that would conclude with reproductive cloning. Realistically, SCNT success will not make reproductive cloning more likely. Embryos produced by SCNT have little if any potential of developing to the point of being born alive. ${ }^{1}$ It is true that the cloned embryos are produced for research, but the eventual aim is to use them for therapy.

Another ethical concern is the source of the donated human eggs (ova) used for SCNT. These need to be donated by healthy women. The concern is that for this research to continue there will be a surge in the need for donor women, and this will substantially increase if SCNT is developed - as it is hoped - into a therapeutic modality with the concern that there will be the potential for exploitation of women in order to satisfy the increasing demand for human eggs.1,22 Egg donation involves the use of hormones to stimulate egg production and an invasive procedure to retrieve the eggs. Donors are usually compensated. Compensation is generally permissible to substitute for lost wages, expenses for the procedure, and the inconvenience caused by possible side effects from the use of hormones to cause superovulation with the major risk, though rare, of ovarian hyperstimulation in addition to the inconvenience of the invasive procedures.1,22 The question is how much these are worth and would money be the reason for volunteering or would it be pure altruism. The average compensation now is $\$ 6,000$ per cycle but probably this amount will increase as the demand increases. In any case, a thorough informed consent must be obtained. ${ }^{22}$

To summarize the previous discussion "Ethical Considerations", one can say that while there is no dispute that the ability to treat serious disease is a great good, it must also be recognized that not all means of achieving a desired good are morally and ethically justifiable.

\section{Religion and Stem Cell Research}

The United States of America is a secular state, yet religion and religious values play an important role in how individuals view the different issues particularly moral and ethical issues and their views become reflected in the politicians' attitudes and opinions and this is further reflected in governmental policies. Therefore, a discussion of stem cell research and its ethical implications cannot be complete without discussing the religious viewpoints. I will limit this discussion to Christianity, Judaism, and Islam, although I believe other religions and sects have views as well. ${ }^{14}$ 


\section{Christianity}

Broadly speaking, Catholic, Orthodox (Greek/Coptic), and conservative Protestant churches have similar views on this topic. They believe that the human embryo is an individual from the moment of fertilization and that it has the right to its own life. They further believe that every intervention not in favor of the embryo is a violation of its right and that no good end justifies the destruction of an embryo. ${ }^{23,24}$ On the other hand, for a lack of a better term, less conservative Protestant churches teach that the embryo has a potential human status, but the life of the embryo has to be weighed against the possible benefit that may result from scientific research. They believe that while the life of an embryo is sacred from the time of fertilization, embryo research may be permitted prior to the primitive streak stage. ${ }^{14}$

\section{Judaism}

Judaism is also nonmonolithic. The main groups of Judaism are Orthodox, conservative, and reform. Broadly speaking, there are some principles in Judaism that pertain to this discussion.

1. Healing is a required obligation..$^{25}$

2. Any activity that contributes to advancement in the world cannot be considered contradicting God's orders. 26

3. God is the one who gave us the power to create new technology, and then we can use it. 16

4. Each activity that has no reason to be prohibited is permitted without having to find a reason for its permissibility. ${ }^{26}$

5. The human fetus $<40$ days of age and certainly the preimplantation embryo do not have full human status. ${ }^{27}$

\section{Islam}

Islam is usually defined as submission to Allah's (God) will will. Mus lims believe that Is lam controls their actions in material as well as spiritual matters. Is lam is commonly described as a way of life. So, a Muslim in performing any act should ask himself whether this act is permissible. O ne has to find if there is a $Q$ uranic injunction on that matter and if not, one has to find out if there is a hadith (saying) of Prophet Muhammad allughale and if not, one has to resort to the opinion of fuqaha
(Islamic legal scholars) who use ijtihād (independent judgment) and have made a concerted effort to come up with a new ruling. 28

The most important consideration in the topic under discussion is when life starts. There is no specific definition of the beginning of life either in the Quran or the hadith collections. It is generally agreed that ensoulment, the breathing of Allah's rūh (spirit) into the fetus, differentiates biological life, which starts at the time of fertilization, from human life. ${ }^{29}$ There is a difference of opinion between scholars as to whether ensoulment occurs at 40 or 120 days, ${ }^{29-31}$ depending on different interpretations of a hadith narrated on the authority of Ibn Mas'ūd. ${ }^{32}$ All scholars agree that embryonic life is entitled to respect even before ensoulment but becomes more so after it occurs. 33

Four Islamic principles may apply to stem cell research:

1. Islam has always encouraged men to contemplate and explore new horizons. ${ }^{34-6}$

2. Prophet Muhammad aلlughale ordered us to seek cure for disease. He said "Allah all did not create a disease without creating a cure for it except senility, so sons of Adam seek cures but do not use harām (forbidden things)". 37

3. All actions are in principle permissible as long as they are not categorically prohibited.

4. In matters in which other invocations are silent the concept of maslaha (public interest) applies: "Where the welfare of people resides, there resides the statute of God." 33

The Muslim World League's Islamic Jurisprudence Council conference in December 2003 held in Mecca, Saudi Arabia, issued a fatwā (religious opinion) regarding this topic, excerpts of which are translated below:

It is permissible to acquire, grow and use stem cells for therapy or scientific research as long as the cells' sources are permissible. Examples of permissible sources are adults who consent as long as it does not inflict harm on them, children whose guardians consent for a legal benefit without inflicting harm on the children, placenta or umbilical 
cord blood with the permission of the parents, spontaneously aborted embryos or those aborted for a legally acceptable cause and with the permission of the parents, and excess fertilized eggs produced during the course of IVF and donated by the parents with assurance that they are not to be used to produce an illegal pregnancy. It is forbidden to obtain or use stem cells if its source is forbidden. Examples of this include fetuses intentionally aborted without a legal medical reason, intentional fertilization between a donated ovum and sperm, and therapeutic cloning. ${ }^{38}$

This last point is unclear. Although it seems to prohibit therapeutic cloning completely, it may be that the prohibition is meant to be if it is just used to create an embryo to be a stem cell donor or in the context of "reproductive" cloning. This probably does not apply to the actual SCNT to generate a tissue that will be transplanted in the donor of the somatic cell or to diagnose and study treatment of a genetic disease in that donor.

Abdulaziz Sachedina, a Muslim professor of religious studies at the University of Virginia, stated "Research on stem cells made possible by biotechnical intervention is regarded as an act of faith in the ultimate will of God as the Giver of all life as long as such an intervention is undertaken with the purpose of improving human health." 39

There has been several published reports on the Islamic perspective of stem cell research by both non-Muslims ${ }^{14,16}$ and Muslims. ${ }^{40-2}$ These authors conclude that Islam permits stem cell research in principle. The latter authors report that the Islamic Republic of Iran is one of the first countries that has produced hESCs. ${ }^{41}$

The Islamic position on stem cell research can be outlined as follows:

1. In principle stem cell research is acceptable due to its therapeutic potential.

2. Fertilized eggs before implantation are not considered fully human because without implantation they cannot survive and develop into a human being.

3. The supernumerary embryos produced dur- ing IVF can not be donated to other couples, and if they will not be used by the same couple, they will have to be destroyed or left to die. Using them for stem cell research is then - at a minimum - acceptable and may even be preferable to their destruction.

4. Islamic scholars agree that creating human embryos for the sole purpose of research is prohibited.

\section{Status of Human Embryonic Stem Cell Research in the United States}

President Bush, by an executive order, allowed human embryonic stem cell research to continue on cell lines created before August 9, 2001.5 The order prevented any funding for subsequent hESC production or SCNT stem cell production. At that time, there were probably 60-70 such lines and only 22 of them could be propagated in culture. However, these cell lines were not found to be useful for therapies because they were potentially contaminated with pathogens from mouse cells. ${ }^{43}$ There are currently approximately 400,000 cryopreserved human preembryos in storage that are not to be used for reproduction but can be used for research. ${ }^{44}$ However, the Federal prohibition significantly limits their use. The U.S. Congress passed a bill that would allow federal grant support for stem cell research, but President Bush vetoed that bill in July 2006, and the U.S. House of Representatives failed to override the veto. 45

Several states have bills under consideration or have passed bills regarding stem cell research. For a more detailed discussion of the status of hESC research in the different states, see Weissman (2005)5 and Okie (2005).22

Klimanskaya et al ${ }^{46}$ were able to develop hESC lines by using only one blastomere, allowing the embryo to continue developing. They used a procedure akin to that used in preimplantation genetic diagnosis (PGD). Numerous reports show that the survival rate of embryos with one blastomere removed is unaffected and that the subsequent development and chances of implantation are the same for both normal embryos and those biopsied for PGD. By avoiding the death of the embryo, the technique might obviate the principle concern of opponents to stem cell research. So far, this technique has had no effect on the ongoing debate. ${ }^{46}$ 


\section{References}

1. Brock DW. Is a consensus possible on stem cell research? Moral and political obstacles. J Med Ethics. 2006;32:36-42.

2. NIH Stem Cell Information Home Page. In Stem Cell Information [World Wide Web site]. Bethesda, MD: National Institutes of Health, U.S. Department of Health and Human Services, 2007 [cited Wednesday, March 28, 2007] Available at $<$ http://stemcells.nih.gov/index>.

3. Wobus AM, Boheler KR. Embryonic stem cells: prospects for developmental biology and cell therapy. Physiol Rev 2005;85:635-78.

4. Sanai N, Alvarez-Buylla A, Berger, MS. Neural stem cells and the origin of gliomas. $\mathrm{N}$ Engl J Med. 2005;353:811-22.

5. Weissman I. Stem cell research: paths to cancer therapies and regenerative medicine. JAMA. 2005;294:1359-66.

6. Takagi Y, Takahashi J, Saiki H, et al. Dopaminergic neurons generated from monkey embryonic stem cells function in a Parkinson primate model. J Clin Invest. 2005;115:102-9.

7. Cummings BJ, Uchida N, Tamaki SJ, et al. Human neural stem cells differentiate and promote locomotor recovery in spinal cord-injured mice. Proc Natl Acad Sci USA. 2005;102:14069-74.

8. $\mathrm{Hu} \mathrm{CH}, \mathrm{Wu} \mathrm{GF}$, Wang $\mathrm{XQ}$, et al. Transplanted human umbilical cord blood mononuclear cells improve left ventricular function through angiogenesis in myocardial infarction. Chinese Med J. 2006;119:1499-506.

9. ClinicalTrials.gov [World Wide Web site]. Bethesda, MD: National Institutes of Health, U.S. Department of Health and Human Services, 2007. Available at <http://www.clinicaltrials.gov>. Accessed 25 Oct 2006.

10. The European Group on Ethics in Sciences and New Technologies. Adoption of an opinion on ethical aspects of human stem cell research and use. Available

http://ec.europa.eu/european_group_ethics/docs/ dp15_en.pdf. [Revised Jan 2001; viewed 28 Mar 2007]. 11. Moise KJ. Contemporaryobgyn.net [World Wide Web site]. What to tell patients about banking cord blood stem cells. Available at http://www.contemporaryobgyn.net/obgyn/article /articleDetail.jsp?id=320177. [Revised 15 Apr 2006; viewed 28 Mar 2007].
12. Juvenile Diabetes Research Foundation. University of Florida. ClinicalTrials.gov [World Wide Web site]. Umbilical cord blood infusion to treat type I diabetes. Bethesda, MD: National Institutes of Health, U.S. Department of Health and Human Services, $2007 . \quad$ Available at www.clinicaltrials.gov/ct/show/NCT00305344. [Updated 12 Sep 2006; viewed 28 Mar 2007].

13. Young B, editor. Emerging stem cell therapies. The role of cord blood banks. A supplement to ObG Management. 2006 Oct. Available at http://www.obgmanagement.com/MedEdLibr/PDFs /OBGSupp_HUCB.pdf.

14. Hug K. Therapeutic perspectives of human embryonic stem cell research versus the moral status of a human embryo-does one have to be compromised for the other? Medicina (Kaunas). 2006;42:10714.

15. Mahoney J. Bioethics and belief: religion and medicine in dialogue. London: Sheed and Ward; 1984. 16. Lampman J. Different faiths, different views on stem cells. Christian Science Monitor. 23 Jul 2001. Available

from http://www.csmonitor.com/2001/0723/p1s2.html. 17. Harris J. Should we experiment on embryos? In Lee R, Morgan D (editors). Birthrights: law and ethics at the beginnings of life. London: Rutledge; 1989:8595.

18. Sandel MJ. Embryo ethics-the moral logic of stem-cell research. N Engl J Med. 2004;351:207-9.

19. Knoepffler N. Stem cell research: an ethical evaluation of policy options. Kennedy Inst Ethics J. 2004;14:55-74.

20. Rickard M. Current issues brief no 5 2002-03: Key ethical issues in embryonic stem cell research. Parliamentary Library. Parliament of Australia [World Wide Web site]. http://www.aph.gov.au/library/pubs/cib/200203/03cib05.htm. [Revised 21 Nov 2002; viewed 28 Mar 2007].

21. Fischbach GD, Fischbach RL. Stem cell: science, policy and ethics. J Clin Invest. 2004;114:1364-70.

22. Okie S. Stem-cell research-signposts and roadblocks. N Engl J Med. 2005;353:1-5.

23. Landry DW, Zucker HA. Embryonic death and the creation of human embryonic stem cells. J Clin Invest. 2004;114:1184-6.

24. Welin S. Ethical issues in human embryonic stem cell research. Acta Obstet Gynecol Scand. 
2002;81:377-82.

25. Walters L. Human embryonic stem cell research: an intercultural perspective. Kennedy Inst Ethics J. 2004;14:3-38.

26. Guigui A. Ethics in medicine and Judaism. In The European Group on Ethics in Sciences and New Technologies (editor). Adoption of an opinion on ethical aspects of human stem cell research and use. Available

at http://ec.europa.eu/european_group_ethics/docs/d p15_en.pdf. [Revised Jan 2001; viewed 28 Mar 2007]:145-9.

27. Sullivan B. Religions reveal little consensus on cloning. MSNBC News [World Wide Web site]. c2004. Viewed Jan 11, 2005. Available from http://msnbc.msn.com/id/3076930.

28. Kamali MH. Principles of Islamic jurisprudence. 3rd ed. Cambridge, UK: Islamic Texts Society;2005.

29. Yassin MN. The inception of human life in the light of statements of the Holy Quran and Sunnah and the opinions of Muslim scholars. J Islam Med Assn. 1990;22:159-67.

30. Athar S, Fadel HE, Ahmad WD, et al. Islamic Medical Ethics. The IMANA Perspective. J Islam Med Assn. 2005;37:33-42.

31. Albar MA. Human development as revealed in the Holy Quran and Hadith. Jeddah, Saudi Arabia: Saudi Publishing House; 1992.

32. Ibn Ḥajar al-'Asqalānī. Fatḥ al-Bārī bi sharh șahīḥ al-Bukhārī. Kitāb al-qadar. Bāb fī al-qadar. Available on-line at http://www.muhadith.org.

33. Sahīh Muslim. Kitāb al-qadar. Bāb kayfiyya alkhalq al-ādamī fì baṭn 'ummihi wa kitāba rizqihi wa ajalihi wa 'amalihi wa shaqāwatihi wa sa`ādatihi. Hadith no. 2643. Available on-line at http://www.muhadith.org.

33. Abū Hāmid Muhammad al-Ghazālī. Ihyyā' 'ulūm aldīn. `Abd al-`Azīz `Izz al-dīn al-Sairawān (editor). 3rd ed. Beirut, Lebanon: Dār al-qalam.

34. Glorious Quran, Chapter 29, Verse 20.

35. Glorious Quran, Chapter 35, Verses 29-30.

36. Glorious Quran, Chapter 7, Verse 185.

37. Sunan Abī Dāwūd. Kitāb al-țibb. Bāb fī al-adwiyya al-makrūha. Hadith no. 3874. Available from http://www.muhaddith.org.

38. Muslim Word League. Islamic Jurisprudence Council Conference, Dec 13-17, 2003, Makka, Saudi Arabia. Fatwa number 3. Regarding stem cells. Available

from

http://www.themwl.org/Fatwa/default.aspx?d=1\&ci $\mathrm{di}=152 \& \mathrm{l}=\mathrm{AR} \& \mathrm{cid}=12$. [Accessed 27 Mar 2007].

39. Sachedina AA. Islamic Perspectives on Research with Human Embryonic Stem Cells. In Ethical issues in human stem cell research. Religious perspectives (Vol 3). Rockville, MD: Governmental Printing Office; 2000. Available from: http://bioethicsprint.bioethics.gov/reports/past_co mmissions/nbac_stemcell3.pdf.

40. Beloucif S. The Muslim's perspective related to stem cell research. In The European Group on Ethics in Science and New Technologies to the European Commission (editor). Adoption of an opinion on ethical aspects of human stem cell research and use. Available at http://ec.europa.eu/european_group_ethics/docs/d p15_en.pdf. [Revised Jan 2001; viewed 28 Mar 2007]:134-8.

41. Larijani B, Zahedi F. Islamic perspective on human cloning and stem cell research. Transplant Proc. 2004;36:3188-9.

42. Aksoy S. Making regulations and drawing up legislation in Islamic counties under conditions of uncertainty with special reference to embryonic stem cell research. J Med Ethics. 2005;31:399-403.

43. Martin MJ, Muotri A, Gage F, et al. Human embryonic stem cells express an immunogenic nonhuman sialic acid. Nat Med. 2005;11;228-32.

44. Weiss R. 400,000 human embryos frozen in U.S. Number at fertility clinics is far greater than previous estimates, survey finds. Washington Post. 2003 May 8;A10.

45. MSNBC News Services. House can't override stem cell veto. [updated $2006 \mathrm{Jul} \mathrm{19}$; cited 2007 Feb 10]. Available from http://www.msnbc.msn.com/id/13934199.

46. Klimanskaya I, Chung Y, Becker S, et al. Human embryonic stem cell lines derived from single blastomeres. Nature. 2006;444(7118):481-5. 